\title{
PROFIL LIPID DARAH AYAM RAS PETELUR YANG DI BERI KITOSAN IRADIASI
}

\section{The Profile of Blood Lipid of Laying Hens Adminestered Chitosan Irradiation}

\author{
Rajali Hotlan Siregar ${ }^{1}$, Diding Latipudin², Andi Mushawwir ${ }^{2}$ \\ ${ }^{1}$ Program Studi Ilmu Peternakan, Fakultas Peternakan, Universitas Padjadjaran \\ Kampus Jatinangor, Jl. Raya Bandung-Sumedang KM.21, Jatinangor, Sumedang, \\ Jawa Barat 45363 \\ ${ }^{2}$ Laboratorium Fisiologi Ternak dan Biokimia, Departemen Nutrisi Ternak dan Teknologi \\ Pakan, Fakultas Peternakan, Universitas Padjadjaran, Bandung \\ Kampus Jatingaor, Jl. Raya Bandung- Sumedang KM.21, Jatinangor, Sumedang, \\ Jawa Barat 45363
}

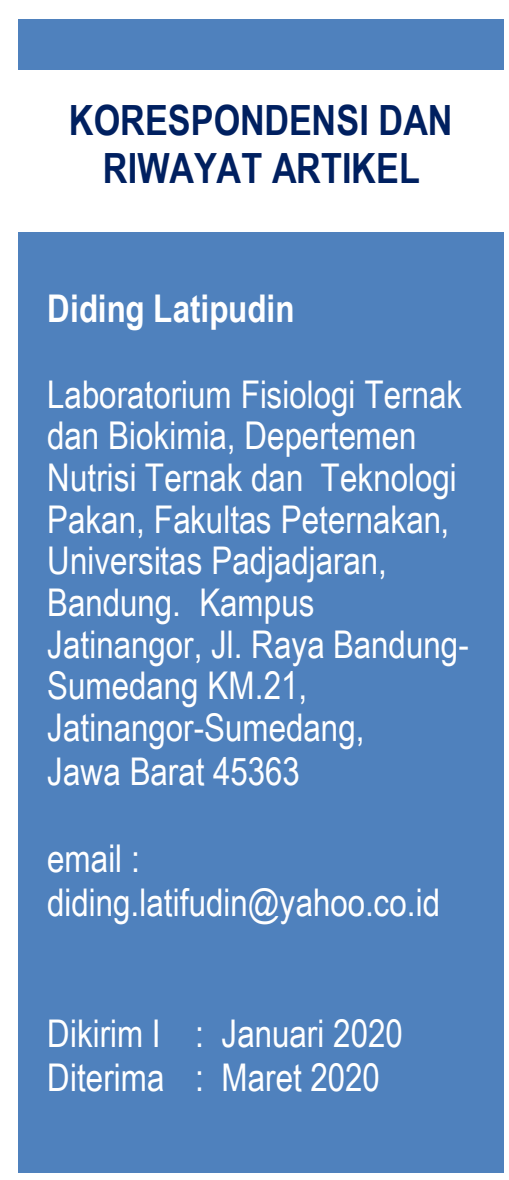

\begin{abstract}
ABSTRAK
Penelitian mengenai kadar kolesterol dan trigliserida darah ayam ras petelur yang diberi kitosan iradiasi dilaksanakan pada bulan Agustus hingga September di peternakan ayam petelur Desa Sukarapih, Kecamatan Sukasari, Kabupaten Sumedang, Jawa Barat. Pengujian sampel darah dilakukan di Laboratorium Fisiologi Ternak dan Biokimia Fakultas Peternakan Universitas Padjadjaran, Kecamatan Jatinangor, Kabupaten Sumedang, Jawa Barat. Penelitian ini dilakukan untuk mengetahui pengaruh pemberian kitosan iradiasi terhadap kadar kolesterol dan trigliserida plasma darah ayam petelur fase layer. Penelitian menggunakan metode eksperimental dengan uji polynomial ortogonal. Terdapat 50 ekor ayam ras petelur fase layer sebagai objek penelitian, dilakukan lima jenis perlakuan yaitu $\mathrm{P} 0=$ tanpa pemberian kitosan, $\mathrm{P} 1=$ ayam petelur diberi kitosan $150 \mathrm{ppm}, \mathrm{P} 2=$ ayam petelur diberi kitosan $200 \mathrm{ppm}, \mathrm{P} 3=$ ayam petelur diberi kitosan 250 ppm , P4 = ayam petelur diberi kitosan 300 ppm. Hasil analisis statistik menunjukkan bahwa pemberian kitosan berbeda nyata $(\mathrm{p}<0,05)$ terhadap kadar kolesterol dan trigliserida dan $250 \mathrm{ppm}$ merupakan yang paling optimal menurunkan kadar kolesterol dan trigliserida.
\end{abstract}

Kata Kunci: layer; kitosan iradiasi; kolesterol; trigliserida 


\section{ABSTRACT}

Research on cholesterol and triglyceride levels in blood of laying hens adminestered chitosan irradiated was carried out in August to September at the laying chicken farm in Sukarapih Village, Sukasari District, Sumedang Regency, West Java. Blood sample was analyzed at the Laboratory of Animal Physiology and Biochemistry of the Faculty of Animal Husbandry, Padjadjaran University, Jatinangor District, Sumedang Regency, West Java. This research was conducted to determine the effect of chitosan irradiation on cholesterol levels and triglyceride levels blood plasma of layer chicken. The research used an experimental method with orthogonal polynomial test. There were 50 laying hens phase layer as research object, five types of treatment, $P O=$ laying hens without Chitosan, $P 1=$ laying hens with granting Chitosan 150 ppm, $P 2=$ laying hens with granting Chitosan 200 ppm, $P 3=$ laying hens with granting Chitosan 250 ppm, and P4 = laying hens with granting Chitosan $300 \mathrm{ppm}$. Based on the statistic analysis result showed that administration of chitosan was significantly different ( $p$ $<0.05)$ for cholesterol and triglyceride levels and $250 \mathrm{ppm}$ was the most optimal way to reduce cholesterol and triglyceride levels.

\section{Keywords: $\quad$ Laying hen, chitosan irradiation, cholesterol, triglyceride}

\section{PENDAHULUAN}

Pakan yang dikonsumsi oleh ayam ras petelur mengandung berbagai nutrisi. Nutrisi dibutuhkan organisme untuk fungsi normal dari sistem tubuh, pertumbuhan, pemeliharaan kesehatan. Lemak merupakan salah satu nutrisi yang sangat penting bagi makhluk hidup. Selain sebagai cadangan energi jangka panjang, lemak juga berfungsi membantu pembuatan hormon dan pembentukan sel.

Kolesterol dan trigliseida adalah contoh lemak yang terdapat didalam plasma darah. Kolesterol dalam tubuh berfungsi sebagai prekursor untuk banyak hormon, termasuk testosteron dan estrogen, menjaga cairan sel membran, dan berkontribusi terhadap pembentukan asam empedu yang membantu mencerna lemak. Trigliserida sebagai cadangan energi jangka panjang. Lipid (asam lemak dan kolesterol) sangat penting dalam poduksi telur karena merupakan precursor utama yolk yang disentesis di dalam sel-sel hati, kemudian ditransport ke dalam ovarium dalam bentuk vitellogenin dan dalam bentuk $\beta$-lipoprotein (Mushawwir dan latipudin, 2013). Selain itu, kolesterol menjadi precursor hormon-hormon steroid (estrogen, progesterone) di dalam selsel granulosa dan theka pada follikel ovarium. Ini brarti bahwa lipid (asam-asam lemak dan kolesterol) sangat dibutuhkan dalam sintesis telur. Kekurangan dan kelebihan lipid darah dalam tubuh dapat mengganggu kesehatan. Untuk menjaga kadar lipid dalam darah normal selain diet makanan sehat perlu diberikan kitosan.

Kitosan (2-asetamida-deoksi--Dglukosa) merupakan kitin deasetilasi, tersebar luas di alam berasal dari eksoskeleton artropoda seperti kepiting, udang, serangga, dan makhluk laut lainnya dalam keluarga crustacea (Crini, 2005; Huang, et al., 2007). Kitosan merupakan jenis polimer alam yang mempunyai bentuk rantai linier (Muzarelli, 1988). Polimer dalam kitosan mengandung kelompok amino dan hidroksil per residu yang memberikan kitosan banyak melakukan kegiatan biologis, seperti, anti inflamasi, antimikroba, hipoglikemik dan hipokolesterolemik dan efek imunostimulator (Mushawwir dan Latipudin, 2012; Xu et al., 2013). Kitosan ditemukan oleh C. Rouget pada tahun 1859, menemukan bahwa kitin yang telah didihkan pada larutan $\mathrm{KOH}$ juga dapat diperlukan dengan $\mathrm{NaOH}$ panas maka akan terjadi pelepasan gugus asetil (proses deasetilasi) yang terikat pada atom nitrogen menjadi gugus amino bebas yang disebut dengan kitosan (Zakaria, 2002). Kecernaan kitosan lebih baik dibandingkan dengan kitin. 
Cara yang ditempuh untuk memperoleh kitosan iradiasi yaitu dengan bantuan sinar gamma. Fungsi iradiasi sinar gamma pada kitosan untuk memutuskan rantai molekul menjadi oligokhitosan.

Pemberian kitosan terhadap hewan dan ternak berdampak terhadap profil biokimia hewan. Hasil penelitian sebelumnya ditunjukkan bahwa kitosan mampu menurunkan kandungan lemak pada mamalia. Kemampuan kitosan mempengaruhi regulasi protein terutama gengen yang terkait dengan sintesis lipid (lemak dan sterol). Melalui penelitian tersebut yang dilakukan Chiu et al., (2015), telah mengkaji lebih jauh serta telah ditunjukkan gen-gen terkait lipogenesis dan protein pengatur sintesis lemak dan strerol. Penelitian ini bertujuan mengetahui level pemberian kitosan iradisi optimal untuk meneurunkan kadar lipid darah ayam ras petelur.

\section{METODE PENELITIAN}

\section{Ternak Percobaan}

Ternak percobaan yang digunakan untuk penelitian ini adalah ayam petelur fase layer sebanyak 50 ekor berumur 29 bulan. Sampel tersebut dipelihara dalam kandang tipe semi close house dengan bentuk battery individual, kandang dibuat menyusun kesamping dengan panjang $1000 \mathrm{~cm}$ x lebar $35 \mathrm{~cm}$ x tinggi depan $42 \mathrm{~cm} \times$ tinggi belakang $37 \mathrm{~cm}$, model ini disekat menjadi 50 pintu dan setiap satu pintu diisi satu ekor ayam. Penelitian ini dilaksanakan dengan menggunakan teknik rancangan acak lengkap. Terdiri dari lima (5) perlakuan penambahan kitosan dengan sepuluh (10) kelompok ulangan, yaitu:

Perlakuan A : Tanpa pemberian kitosan (P0) Perlakuan B : Kitosan 150 ppm dalam air minum $(\mathrm{P} 1)$

Perlakuan C : Kitosan 200 ppm dalam air minum (P2)

Perlakuan D : Kitosan 250 ppm dalam air minum (P3)

Perlakuan E : Kitosan 300 ppm dalam air minum (P4)

\section{Pembuatan Larutan Kitosan}

Kitosan yang digunakan dalam penelitian ini yaitu kitosan yang telah diiradiasi dengan menggunakan teknik radiasi nuklir terhadap kondisi fisiobiokimiawi ternak unggas. Kitosan hasil radiasi dalam bentuk cairan diperoleh dari Pusat Aplikasi Isotop dan Radiasi (PAIR), Badan Tenaga Nuklir Indonesia (BATAN), Pasar Jumat Jakarta. Larutan kitosan dibuat dengan cara $1 \mathrm{~mL}$ kitosan induk dicampurkan ke dalam air hingga $1 \mathrm{~L}$, sehingga diperoleh konsentrasi larutan kitosan $50 \mathrm{ppm}$. Kitosan diberikan dalam bentuk cair yang dicampurkan kedalam air minum, kemudian diberikan kepada ternak percobaan sesuai dengan perlakuan

\section{Analisis Statistika}

Data respon penelitian dianalisis dengan menggunakan metode ortogonal polinomial. Suatu derajat polynomial ke-n digunakan untuk mengetahui hubungan antara peubah respon $\mathrm{Y}$ dan peubah predictor $\mathrm{X}$ diujikan sebagai berikut :

$$
\mathrm{Y}=\alpha+\beta_{1} \mathrm{X}+\beta_{2} \mathrm{X}^{2}+\ldots .+\beta_{\mathrm{n}} \mathrm{X}^{\mathrm{n}}
$$

Data yang diperoleh telah dianalisis dengan software SPSS IBM 21.

\section{HASIL DAN PEMBAHASAN}

Pengaruh pemberian berbagai level kitosan iradiasi dalam air minum terhadap kadar kolesterol plasma darah ayam ras petelur, berdasarkan hasil penelitian dapat dilihat pada Tabel 1. Hasil uji polynomial orthogonal menunjukkan bahwa pemberian kitosan iradiasi berpengaruh nyata terhadap kadar kolesterol plasma darah ayam ras petelur $\quad(\mathrm{P}<0,05)$. Berdasarkan hasil penelitian menunjukkan bahwa semakin tinggi level pemberian kitosan iradiasi menyebabkan penurunan kadar kolesterol dengan signifikan. Hasil uji beda contras orthogonal (Tabel 1) menunjukkan rata-rata kadar kolesterol plasma darah ayam ras petelur berbeda nyata $(\mathrm{P}<0,05)$ pada berbagai kelompok perlakuan. 
Tabel 1. Hasil Uji Beda Contras Orthogonal terhadap Rata-Rata Kadar Kolesterol Ayam Ras Petelur dengan Pemberian Kitosan Iradiasi

\begin{tabular}{ccc}
\hline Perlakuan & $\begin{array}{c}\text { Rata-rata kolesterol } \\
(\mathrm{mg} / \mathrm{dL})\end{array}$ & $\begin{array}{c}\text { Rata-rata Trigligliserida } \\
(\mathrm{mg} / \mathrm{dL})\end{array}$ \\
\hline P0 & $125,11^{\mathrm{a}}$ & $1282,82^{\mathrm{a}}$ \\
P1 & $115,11^{\mathrm{b}}$ & $1280,29^{\mathrm{b}}$ \\
P2 & $97,98^{\mathrm{c}}$ & $685,20^{\mathrm{c}}$ \\
P3 & $94,67^{\mathrm{c}}$ & $524,46^{\mathrm{d}}$ \\
P4 & $83,38^{\mathrm{c}}$ & $504,83^{\mathrm{d}}$ \\
\hline
\end{tabular}

Keterangan: Notasi huruf yang berbeda pada kolom yang sama menunjukan perbedaan yang nyata $(\mathrm{P}<0,05)$

Pada Tabel 1, tampak bahwa rata-rata kadar kolesterol plasma darah ayam ras petelur tanpa pemberian kitosan iradiasi $(125,11 \mathrm{mg} / \mathrm{dL})$, berbeda nyata paling tinggi $(\mathrm{P}>0,05)$ dibandingkan rata-rata kadar kolesterol plasma darah kelompok ayam ras petelur yang diberi kitosan iradiasi sebanyak 150 ppm, 200 ppm, 250 ppm dan 300 ppm, yaitu masing masing $115,11 \mathrm{mg} / \mathrm{dL} ; 97,98$ $\mathrm{mg} / \mathrm{dL} ; 94,67 \mathrm{mg} / \mathrm{dL}$ dan 83,38 $\mathrm{mg} / \mathrm{dL}$. Perbedaan rata-rata kadar kolesterol yang nyata $(\mathrm{P}<0,05)$ juga terjadi antara kelompok ayam yang diberi perlakuan kitosan iradiasi 150 ppm dengan yang diberi 200 ppm, 250 ppm dan 300 ppm, sedangkan antar perlakuan 200 ppm, 250 ppm dan 300 ppm tidak berbeda nyata (Tabel 1).

Penurunan rata-rata kadar kolesterol seiring dengan bertambahnya konsentrasi pemberian kitosan iradiasi dalam air minum, dapat diduga efektifitasnya melalui analisis kolerasi regresi. Penurunan kadar kolesterol tersebut dipengaruhi oleh level pemberian kitosan sebesar $92,221 \%$ atau koefisen determinasinya 0,92221 . Terdapat derajat hubungan yang sangat tinggi antara peningkatan level pemberian kitosan iradiasi dengan penurunan kadar kolesterol plasma darah, yaitu r=0,96026 (Gambar 1)

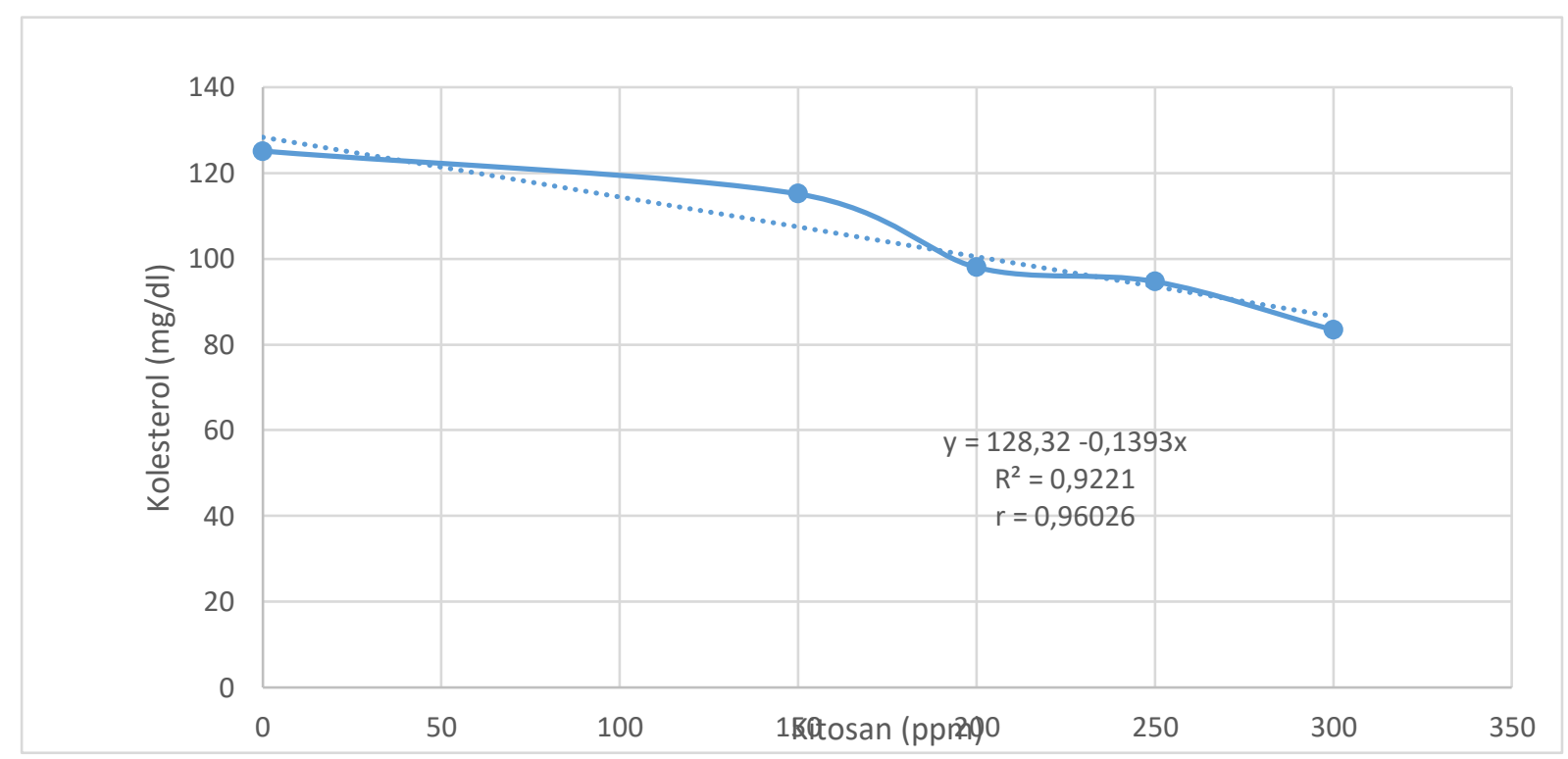

Gambar 1. Grafik Analisis Kolerasi Regresi Kadar kolesterol Ayam Ras Petelur dengan Pemberian Kitosan Iradiasi 
Berdasarkan analisis kolerasi regresi besarnya penurunan kadar kolesterol dapat diduga melalui persamaan atau model prediksi yaitu $\mathrm{y}=128,32-0,139 \mathrm{x}$. Berdasarkan model pendugaan tersebut dapat dijelaskan bahwa penambahan sebanyak 0,139 ppm kitosan iradiasi menyebabkan penurunan kadar kolesterol sebanyak $1 \mathrm{mg} / \mathrm{dL}$ plasma darah. Berdasarkan penelitian ini tampak kadar kolesterol ayam ras petelur tanpa diberi kitosan iradiasi paling tinggi dibandingkan dengan perlakuan diberi kitosan iradiasi. Kadar kolesterol menurun seiring dengan betambahnya level pemberian kitosan iradiasi dalam air minum, meskipun kadar kolesterol tampak tidak berbeda dengan pemberian level kitosan $200-300$ ppm. Level pemberian kitosan (150 -300 ppm) berbeda nyata lebih rendah dibandingkan tanpa pemberian kitosan. Hasil penelitian ini menunjukkan bahwa kitosan iradiasi efektif menurunkan konsentrasi kolesterol yang berdisitribusi ke dalam plasma darah ayam ras petelur.

Pemberian level kitosan iradiasi 200 ppm dalam air minum sudah efektif untuk menurunkan kadar kolesterol plasma darah dibandingkan dengan pemberian $150 \mathrm{ppm}$ $(\mathrm{P}<0,05)$. Efektifitas yang sama tampak dengan pemberian 250 dan $300 \mathrm{ppm}$. Efektifitas kitosan iradiasi dalam menurunkan kadar kolesterol plasma darah menunjukkan bahwa kitosan iradiasi dengan berat molekul yang rendah, secara biokimiawi mampu berperan menghambat transport kolesterol dari jaringan tubuh ke sel-sel hati. Selain menghambat transport kolesterol, kitosan juga mampu mereduksi peran enzim - enzim yang terlibat dalam biosintesis kolesterol di sel - sel jaringan tubuh.

Transport kolesterol dari jaringanjaringan tubuh menuju sel-sel hati adalah Hightdensity Lippoprotein (HDL). Berdasarkan penelitian Maitani et al., (2001), menunjukkan penurunan aktivitas transport kolesterol melalui plasma darah oleh HDL maupun LDL sebagai dampak injeksi kitosan. Hasil penelitian yang lain juga menunjukkan peningkatan absorpsi kolesterol oleh sel-sel hati dengan pemberian kitosan (Gopalakannan dan Arul, 2006; Mushawwir dkk., 2019, 2020). Hasil penelitian ini menegaskan bahwa peningkatan absorpsi ke dalam sel - sel hati menyebabkan kadar kolesterol yang bersirkulasi di dalam plasma darah menjadi lebih rendah.

Penurunan kadar kolesterol plasma darah sebagai dampak pemberian kitosan iradiasi berdasarkan hasil penelitian ini, juga menunjukkan bahwa pemanfaatan kolesterol oleh sel-sel hati sebagai prekursor hormonehormon strerol di yolk (kuning telur) mengalami peningkatan. Mushawwir dan Latipudin, (2013) mengemukakan gen yang menstimulasi sterodoigenesis hormon hormon sterol dari precursor kolesterol adalah gen HSD - 17 $\beta$. Aktivitas gen tersebut meningkat dengan ketersediaan prekursor kolesterol di dalam sel - sel hati. Hasil - hasil penelitian sebelumnya menunjukkan bahwa pemberian kitosan meningkatkan aktivitas gen yang berperan dalam sterodoigenesis, sebagai dampak ketersediaan kolesterol di dalam liver (Cuesta et al., 2003 ; Esteban et al., 2001; Gopalakannan et al., 2000).

Berdasarkan hasil-hasil penelitian terdahulu serta hasil penelitian ini, efektifitas kitosan iradiasi dalam menurunkan level kolesterol plasma darah tampaknya bukan hanya disebabkan oleh penurunan transport kolesterol ke dalam plasma. Penyebab lain, juga diakibatkan oleh kemampuan kitosan dalam meningkatkan absorpsi kolesterol ke dalam sel-sel hati, serta pemanfaatannya sebagai prekursor sterodoigenesis, untuk memproduksi hormone-hormon steroid.

Pengaruh pemberian berbagai kitosan iradiasi dalam air minum terhadap kadar trigliserida plasma darah ayam ras petelur, berdasarkan hasil penelitian dapat dilihat pada Tabel 1. Hasil uji polynomial orthogonal menunjukan bahwa pemberian kitosan iradiasi berpengaruh nyata terhadap kadar trigliserida plasma darah ayam ras petelur $(\mathrm{P}<0,05)$. Berdasarkan hasil 
penelitian menunjukkan bahwa semakin tinggi level pemberian kitosan iradiasi menyebabkan penurunan kadar trigliserida dengan signifikan. Hasil uji beda contras orthogonal (Tabel 1) menunjukkan rata-rata kadar trigliserida plasma darah ayam ras petelur berbeda nyata $(\mathrm{P}<0,05)$ pada berbagai kelompok perlakuan.

Pada Tabel 1, tampak bahwa ratarata kadar trigliserida plasma darah ayam ras petelur tanpa pemberian kitosan iradiasi $(1282,825 \mathrm{mg} / \mathrm{dL})$, berbeda nyata paling tinggi $(\mathrm{P}>0,05)$ dibandingkan rata-rata kadar trigliserida plasma darah kelompok ayam ras petelur yang diberi kitosan iradiasi sebanyak 150 ppm, 200 ppm, 250 ppm dan 300 ppm, yaitu masing masing 1280,298 $\mathrm{mg} / \mathrm{dL}$; $685,205 \mathrm{mg} / \mathrm{dL} ; \quad 524,461 \mathrm{mg} / \mathrm{dL}$ dan $504,833 \mathrm{mg} / \mathrm{dL}$. Perbedaan rata-rata kadar trigliserida yang nyata $(\mathrm{P}<0,05)$ juga terjadi antara kelompok ayam yang diberi perlakuan kitosan iradiasi $150 \mathrm{ppm}$ dibandingkan dengan perlakuan 200 ppm, $250 \mathrm{ppm}$ dan $300 \mathrm{ppm}$. Begitupula antara perlakuan 200 dibandingkan dengan perlakuan 250 ppm dan 300 ppm, sedangkan antara perlakuan 250 dan 300 menunjukkan hasil yang tidak berbeda nyata seperti ditunjukkan Tabel 1.

Penurunan rata-rata kadar trigliserida seiring dengan bertambahnya konsentrasi pemberian kitosan iradiasi dalam air minum, dapat diduga efektifitasnya melalui analisis kolerasi regresi. Penurunan kadar trigliserida tersebut dipengaruhi oleh level pemberian kitosan sebesar $75,72 \%$ atau koefisen determinasinya 0,7572 . Terdapat derajat hubungan yang sangat tinggi antara peningkatan level pemberian kitosan iradiasi dengan penurunan kadar plasma darah, yaitu $\mathrm{r}=0,8702$ (Gambar 2).

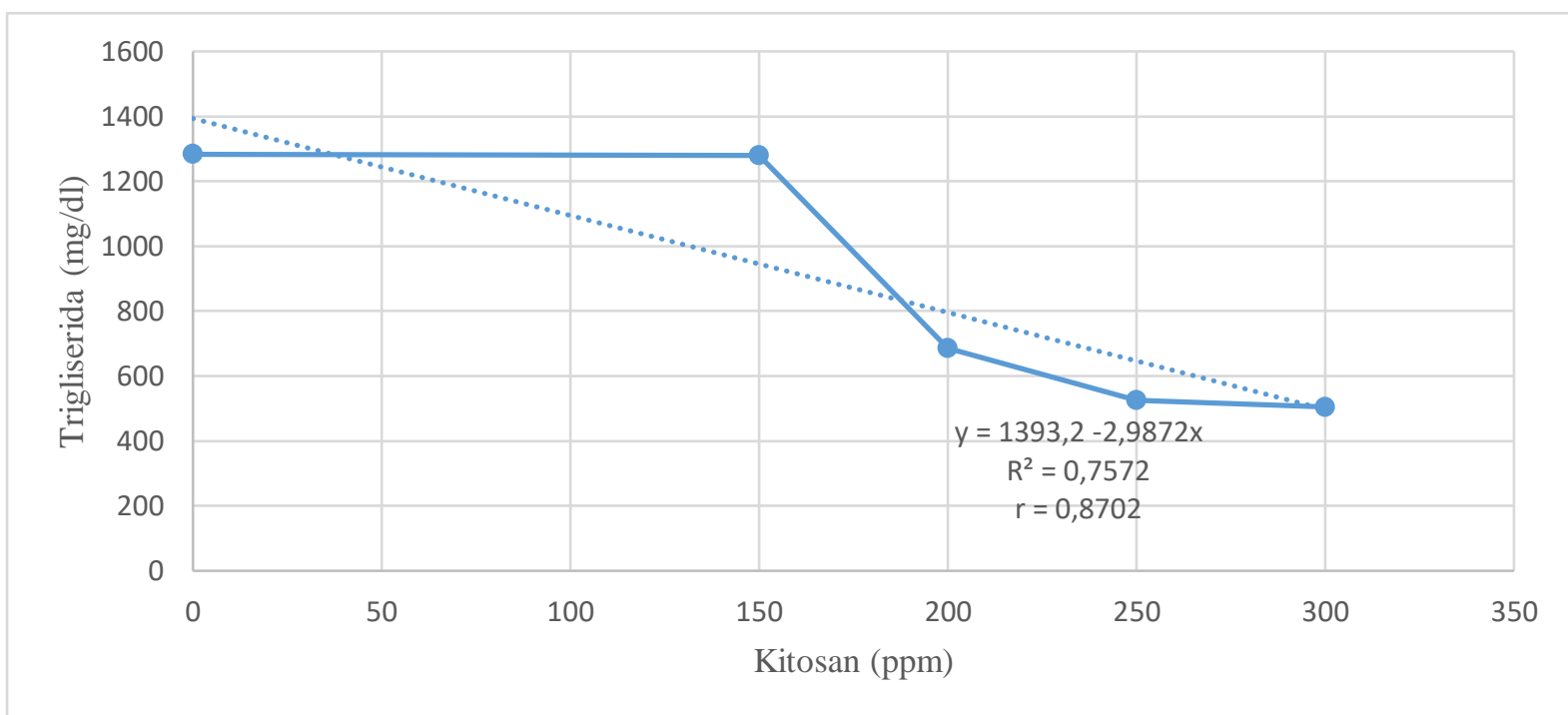

Gambar 2. Grafik Analisis Kolerasi Regresi Kadar Trigliserida Ayam Ras Petelur dengan Pemberian Kitosan Iradiasi

Berdasarkan analisis kolerasi regresi besarnya penurunan kadar Trigliserida dapat diduga melalui persamaan atau model prediksi yaitu $\mathrm{y}=1393,2-2,9872 \mathrm{x}$. Berdasarkan model pendugaan tersebut dapat dijelaskan bahwa penambahan sebanyak 2,987 ppm kitosan iradiasi menyebabkan penurunan kadar Trigliserida sebanyak 1 $\mathrm{mg} / \mathrm{dL}$ plasma darah.
Hasil penelitian ini menunjukkan efektifitas kitosan iradiasi terhadap penurunan kadar trigliserida ayam ras petelur $(524,46$ $\mathrm{mg} / \mathrm{dL}$ ) tampak dengan pemberian level kitosan iradiasi sebanyak $250 \mathrm{ppm}$ dalam air minum $(\mathrm{P}<0,05)$, lebih rendah dibandingkan dengan kadar trigliserida plasma darah yang diberi kitosan iradiasi dengan level 150 dan 200 ppm. Efektifitas kitosan ini terjadi karena kitosan mampu meningkatkan katabolisme 
lipid, khususnya asam - asam lemak. Hasil penelitian Chiu et al. (2015), Suplementasi kitosan secara signifikan meningkatkan laju lipolisis, menurunkan laju hipertrofi adiposit, akumulasi trigliserida, dan aktivitas lipase lipoprotein dalam jaringan adiposa epididimis, serta menurunkan aktivitas enzimenzim dihati yang terkait biosintesis lipid. Suplementasi kitosan secara signifikan dilaporkan dapat mengaktifkan adenosine monophosphate (AMP)-activated protein kinase (AMPK) fosforilasi dan diet tinggi lemak yang menginduksi ekspresi faktor transkripsi lipogenik (Peroxisome Proliferator-Activated Receptor Gamma/ PPAR- $\gamma$ dan sterol receptor element-binding protein 1c/SREBP1c) di hati dan jaringan adipose (Tang et al., 2005; Mushawwir et al., 2017, 2018; Dinana dkk., 2019)

Hasil - hasil penelitian terdahulu terkait peran gen -gen yang terlibat dalam pembentukan trigliserida, ditunjukkan bahwa suplementasi kitosan secara signifikan menghambat ekspresi gen lipogenik, antara lain Fatty Acid Syntase (FAS), 3-Hydroxil-3metil-glutaril Co-A Reductase (HMG-CoA), Fatty Acid Transport 1 (FATP1), dan fatty acid binding protein 4 (FABP4) di hati dan jaringan adipose hewan percobaan yang diberi pakan berlemak tinggi (Tang, et al., 2005). Penghambatan gen-gen lipogenik menyebabkan pembentukan triglisrida mengalami penurunan.

\section{SIMPULAN}

Berdasarkan hasil penelitian disimpulkan pemberian kitosan iradiasi melalui air minum mampu menurunkan kadar kolesterol dan trigliserida plasma darah ayam ras peterlur. Kitosan iradiasi dengan level 250 ppm di dalam air minum merupakan level paling efektif menurunkan kadar lipid dalam plasma darah ayam ras petelur. Pemberian kitosan iradiasi pada ayam ras petelur untuk menurunkan kadar kolesterol dan trigliserida plasma darahnya disarankan menggunakan kitosan iradiasi dengan level $250 \mathrm{ppm}$.

\section{UCAPAN TERIMA KASIH}

Penelitian ini merupakan kerjasama antara Fakultas Peternakan dengan PAIRBATAN, oleh karena itu penulis menyampaikan terimakasih kepada Laboratorium Fisiologi Ternak dan Biokimia yang telah membiayai dan mengikutkan penulis dalam rangkaian penelitian terkait kerjasama tersebut. Begitu pula Adang Sudrajat yang telah menuntun dalam analisis sampel

\section{DAFTAR PUSTAKA}

Basmacioglu, H. and M. Ergul. 2005. Research on the factor affecting cholesterol content and some other characteristics of eggs in laying hens. Turk. J. Vet. Anim. Sci. 29:157-164.

Chiu, C.Y., I.L. Chan, T.H. Yang, S.H. Liu and M.T. Chiang. 2015. Supplementation of chitosan alleviates high-fat diet-enhanced lipogenesis in rats via adenosine monophosphate (amp)-activated protein kinase activation and inhibition of lipogenesisassociated genes. J. Agric. Food. Chem. 63:2979-2988.

Crini, G. 2005, Recent Developments in polysaccharide-based materials used as adsorbents in wastewater treatment, Prog. Polym. Sci. 30:38-70.

Cuesta, A., M.A. Esteban and J. Meseguer. 2003. In vitro effect of chitin particles on the innate cellular immune system of gilhead seabream (Sparus aurata L.). Fish and Shellfish Immunology. 15:111.

Dinana, A., D. Latipudin, D. Darwis dan A. Mushawwir. 2019. Profil enzim transaminase ayam ras petelur yang diberi kitosan iradiasi. J. Nutrisi Ternak Tropis dan Ilmu Pakan 1:6-15.

Esteban, M.A., A. Cuesta, J, Ortuno and J. Meseguer. 2001. Immunomodulatory effects of dietary intake of chitin in gilhead seabream (Sparus aurata L.) innate immune response. Fish and Shellfish Immunology. 11:303-315. 
Gopalakannan, A., G. I. Jasmine, S.A. Shanmugam and G. Sugumar. 2000. Application of proteolytic enzyme, papain for the production of chitin and chitosan from shrimp waste. J. of Marine Biol. Assoc. of India 42:167172.

Gopalakannan, A. and A. Venkatesan. 2006. Immunomodulatory effects of dietary intake of chitin, chitosan and levamisole on the immune system of Cyprinus carpio and control of Aeromonas hydrophila infection in ponds. Aquaculture.255:179-187.

Huang, R. L., Y. L. Yin, M. X. Li, G. Y. Wu, T. J. Li, L. L. Li, C. B. Yang, J. Zhang, B. Wang, Z. Y. Deng, Y. G. Zhang, Z. R. Tang, P. Kang, and Y. M. Guo. 2007. Dietary oligochitosan supplementation enhances immune status of broilers. J. Sci. Food Agric. 87:153-159.

Maitani, Y. H., J. Soeda, S. Wang and K. Takayana. 2001. Modified ethanol injection method for liposome containing $\beta$-sitosterol $\beta$-D-glucoside. J. Liposome Res. 11:115-125.

Mushawwir, A. dan D. Latipudin. 2012. Respon fisiologi thermoregulasi ayam ras petelur fase grower dan layer. Proseding seminar zootechniques for Indogeneous resources development, ISAA Fakultas Petenakan Universitas Diponegoro. Proceeding of National Seminar on Zootechniques. 1: 23-27.

Mushawwir, A. dan D. Latipudin. 2013. Biologi Sintesis Telur : Perspektif Fisiologi, Biokimia dan Molekuler Produksi Telur. Graha Ilmu, Yogyakarta.

Mushawwir, A., U. H. Tanuwiria, K.A. Kamil, L. Adriani and R. Wiradimadja. 2017. Effects of volatile oil of garlic on feed utilization, blood biochemistry and performance of heat-stressed japanese quail. Asian Journal of Poult. Sci. 11:83-89.

Mushawwir, A., U.H. Tanuwiria, K.A. Kamil, L. Adriani, R. Wiradimadja and N. Suwarno. 2018. Evaluation of haematological responses and blood biochemical parameters of heatstressed broilers with dietary supplementation of Javanese Ginger powder (Curcuma xanthorrhiza) and Garlic Extract (Allium sativum). International J. of Poult. Sci .17:452458.

Mushawwir, A., N. Suwarno, A.A. Yulianti dan R. Permana. 2019. Dampak pemberian minyak atsiri bawang putih terhadap histologi illeum itik cihateup fase pertumbuhan yang dipelihara secara ekstensif. J. Peternakan Sriwijaya. 8:35-44.

Mushawwir, A., A.A. Yulianti dan N. Suwarno. 2020. Histologi liver burung puyuh dengan pemberian minyak atsiri bawang putih. J. Ilmu dan Teknologi Peternakan. 8:1-7.

Tang, Z.R., Y.L. Yin, C.M. Nyachoti, R.L.Huang, T.J. Li, C.B. Yang, X.J. Yang, J. Gong, J. Peng, D.S. Qi, J.J. Xing, Z.H. Sun and M.Z. Fan. 2005. Effect of dietary supplementation of chitosan and galacto-mannanoligosaccahride on serum parameters and the insulin like factor-I mRNA expression in early-weaned piglets. Domest. Anim. Endrocrinol. 28:430441.

Xu,Y., B. Shi, S. Yan, T. Li, Y. Guo and J. Li. 2013. Effect of chitosan on body weight gain, growth hormone and intestinal morphology in weaned Pigs. Asian Australas. J. Anim. Sci. 26:1484-1489.

Zakaria, M. B., M. J. Jais, Wan-Yaacob Ahmad, M. R. Othman dan Z. A. Harahap. 2002. Penurunan kekeruhan efluen industri Minyak Sawit (EIMS) oleh Koagulan Konvensional dan Kitosan. Prosiding Seminar Bersama UKM-ITB. Universitas Kebangsaan Malaysia. Malaysia 